\title{
UJI INVITRO EKSTRAK \\ BAWANG HUTAN (Eleutherine palmifolia.(Mill) Urb) TERHADAP BAKTERI Vibrio harveyi PENYEBAB PENYAKIT VIBRIOSIS PADA BUDIDAYA IKAN
}

\author{
Safratilofa \\ Program Studi Budidaya Perairan, Fakultas Pertanian Universitas Batanghari \\ J1. Slamet Riyadi, Broni Jambi, 36122. Telp. +6074160103 \\ Email korespondensi : osa.safra@yahoo.com
}

\begin{abstract}
Bacterial attack is a major abstacle in increasing production of aquaculture activities such as Vibrio harveyi which can cause Vibriosis desease. This research focused on the use of forest extracted onion to achid and remediate the fish diseases caused by bacteria of extracted onion. There was obtained by doing in vitro test using inhibitory test. Concentration of forest onion extract used is 5 $\mathrm{mg} / \mathrm{ml} .10 \mathrm{mg} / \mathrm{ml}, 20 \mathrm{mg} / \mathrm{ml}, 40 \mathrm{mg} / \mathrm{ml}$, negative control ( $\mathrm{K}$-) using steril aquades, and positive control $(\mathrm{K}+)$ using antibiotic Chloramphenicol $5 \mathrm{mg} / \mathrm{ml}$ and 30 $\mathrm{mg} / \mathrm{ml}$. According to inhibitory test, clear zone was acthieved at 1,3 cm with the concentration of $40 \mathrm{mg} / \mathrm{ml}$. The result show the higher extracted onion doses concentration, the highe inhibitory power.

Keywords : Eleutherine palmifolia.(Mill) Urb, Vibrio harveyi, in vitro
\end{abstract}

\begin{abstract}
Abstrak
Serangan penyakit bakterial merupakan satu kendala utama dalam peningkatan produksi kegiatan budidaya ikan seperti Vibrio harveyi yang dapat menyebabkan penyakit Vibriosis. Tujuan yang ingin dicapai dalam penelitian ini adalah untuk mendapatkan dosis terbaik dari aplikasi pemanfaatan ekstrak bawang hutan secara invitro sebagai upaya pencegahan dan pengobatan pada bakteri penyebab penyakit dalam budidaya ikan. Kosentrasi ekstrak bawang hutan yang digunakan yaitu5 $\mathrm{mg} / \mathrm{ml}, \quad 10 \mathrm{mg} / \mathrm{ml}, 20 \mathrm{mg} / \mathrm{ml}, \quad 40 \mathrm{mg} / \mathrm{ml}$, kontrol negatif (K-) dengan menggunakan akuades steril, dan kontrol positif $(\mathrm{K}+)$ dengan menggunakan antibiotik Chloramphenicol $5 \mathrm{mg} / \mathrm{ml}$ dan $30 \mathrm{mg} / \mathrm{ml}$. Berdasarkan zona bening yang diperoleh pada uji daya hambat ekstrak bawang hutan bahwakonsentrasi terbesar yang mampu menghambat pertumbuhan bakteri $V$. Harveyi sebesar 1.3 $\mathrm{cm}$ pada konsentrasi $40 \mathrm{mg} / \mathrm{ml}$. Semakin tinggi konsentrasi daya hambat yang dihasilkan semakin besar.

Kata Kunci: Eleutherine palmifolia.(Mill) Urb, Vibrio harveyi, in vitro
\end{abstract}




\section{PENDAHULUAN}

Pengembangan teknologi budidaya ikan secara intensif untuk meningkatkan hasil produksi dapat berakibat pada penurunan kualitas perairan, sehingga menyebabkan stress yang dapat berdampak pada serangan penyakit.Upaya pencegahan terhadap serangan penyakit yang dapat dilakukan yaitu dengan penggunaan fitofarmaka, vaksin dan probiotik. Fitofarmaka memiliki beberapa keunggulan dibandingkan kegiatan pencegahan lainnya, yaitu dapat dibuat dengan teknik sederhana serta tidak menimbulkan kerusakan lingkungan untuk pemakaian dalam waktu yang lama (BPPOM, 2005).

Bawang hutan (Eleutherine palmifolia) dapat digunakan sebagai salah satu jenis fitofarmaka. Tanaman ini digunakan sebagai obat oleh masyarakat Sulawesi Tenggara. Tanaman ini banyak ditemukan di daerah Kalimantan sehingga disebut juga bawang dayak. Selain itu, dibeberapa daerah di Indonesia, tanaman ini juga dikenal dengan nama bawang mekah, bawang sabrang, bawang hantu, dan bawang arab (Naafi'ah, 2014).

Potensi ekstrak bawang hutan (E. palmifolia) sebagai obat herbal antimikroba telah dibuktikan pada beberapa penelitian seperti dapat menghambat beberapa jenis bakteri dan jamur sepertiStaphylococcus aureus (Ifesanet al., 2009; Puspadewi dkk., 2013), Salmonella typhi (Naafi'ah, 2014), Streptococcus pyogenes (Kamillah, 2014) dan kapang Trichophyton rubrum (Puspadewi dkk., 2013).

Beberapa hasil penelitian lainnya menunjukkan bahwa semakin tinggi kosentrasi ekstrak bawang dayak (E. palmifolia) maka daya hambat terhadap bakteri semakin besar (Puspadewi dkk., 2013). Kosentrasi ekstrak bawang hutan(E. palmifolia) $40 \mathrm{mg} / \mathrm{ml}$ memiliki aktivitas antibakteri yang paling baik dibandingkan dengan kosentrasi $10 \mathrm{mg} / \mathrm{ml}$ dan $20 \mathrm{mg} / \mathrm{ml}$ dalam menghambat bakteri Staphylococcus aureus (Firdaus, 2014) dan bakteriEscherichia coli (Amanda, 2014). Selain itu, perbedaan bakteri yang digunakan juga menunjukkan hasil daya hambat yang berbeda (Kamillah, 2014).Berdasarkan latar belakang tersebut maka dilakukanlah penelitian mendapatkan dosis terbaik dari aplikasi pemanfaatan ekstrak bawang hutan secara invitro sebagai upaya pencegahan dan pengobatan pada bakteri penyebab penyakit dalam budidaya ikan

\section{METODOLOGI PENELITIAN \\ Pembuatan serbuk dan Ekstraksi etanol bawang hutan}

Umbi bawang hutan yang telah berbunga atau berumur 3-4 bulan dibersihkan kemudian diiris tipis-tipis dan dikeringkan di oven pada suhu $60^{\circ} \mathrm{C}$ selama 48 jam. Selanjutnya diblender dan diayak hingga menghasilkan serbuk simplisia bawang hutan.

Serbuk bawang hutan kemudian diekstraksi dengan pelarut etanol $96 \%$ dengan perbandingan 1:4 (w/v). Proses maserasi kinetik dilakukan pada suhu ruang selama 24 jam dengan menggunakanmagnetic stirrerdengan tiga kali pergantian etanol pada serbuk yang sama atau disebut maserasi bertingkat. Hasil maserasi pertama, kedua dan ketiga disaring menggunakan kertas saring Whatman no 42.

Tepung sisa saringan dimaserasi kembali sebanyak dua kali dengan metode yang sama dengan maserasi pertama. Hasil maserasi dipekatkan dengan 
evaporatorvacum pada suhu $40^{\circ} \mathrm{C}$ sehingga menghasilkan ekstrak etanol bawang hutan.

\section{Uji Daya HambatMetode Diffusi Agar}

Uji daya hambatpada penelitian menggunakan metode diffusi agar. Ekstrak bawang hutan dibuat dengan kosentrasi berbeda yaitu $5 \mathrm{mg} / \mathrm{mL}, 10 \mathrm{mg} / \mathrm{mL}, 20$ $\mathrm{mg} / \mathrm{mL}, 40 \mathrm{mg} / \mathrm{mL}$, kontrol positif $(\mathrm{K}+)$ dengan menggunakan antibiotik Chloramphenicol $30 \mathrm{mg} / \mathrm{mL}$ dan kontrol negatif (K-) hanya menggunakan akuades steril. Biakan murni Aeromonas hydrophylasebanyak 1 ose di kultur pada $25 \mathrm{ml}$ media TSB (Tryptic Soy Broth) kemudian diinkubasi dalam waterbath shakerselama 24 jam pada suhu $37^{\circ} \mathrm{C}$. kemudian dilakukan pengenceran berseri sehingga diperoleh kepadatan bakteri $10^{8} \mathrm{CFU} / \mathrm{ml}$. Sebanyak $50 \mu \mathrm{l}$ suspensi bakteri disebar pada media Tryptic Soy Agar (TSA) untuk isolat A. hydrophyla. Kertas cakram steril dicelupkan ke stok ekstrak bawang hutan kemudian ditempelkan pada media yang telah disebar bakteri. Ulangi kembali pada perlakuan lainnya dengan metode yang sama. Setiap perlakuan dosis diberi penanda. Setiap perlakuan dosis dilakukan pengulangan sebanyak tiga kali. Selanjutnya diinkubasi selama 24 jam pada suhu $37^{\circ} \mathrm{C}$. Setelah diinkubasi dilakukan pengukuran diameter zona hambat.

\section{HASIL DAN PEMBAHASAN}

Hasil pengamatan terhadap zona bening dapat dilihat pada (Gambar 1.)Berdasarkan zona bening yang diperoleh pada uji daya hambat ekstrak bawang hutan bahwakonsentrasi terbesar yang mampu menghambat pertumbuhan bakteri $V$. Harveyi pada konsentrasi $40 \mathrm{mg} / \mathrm{ml}$ sebesar $1.3 \mathrm{~cm}$.

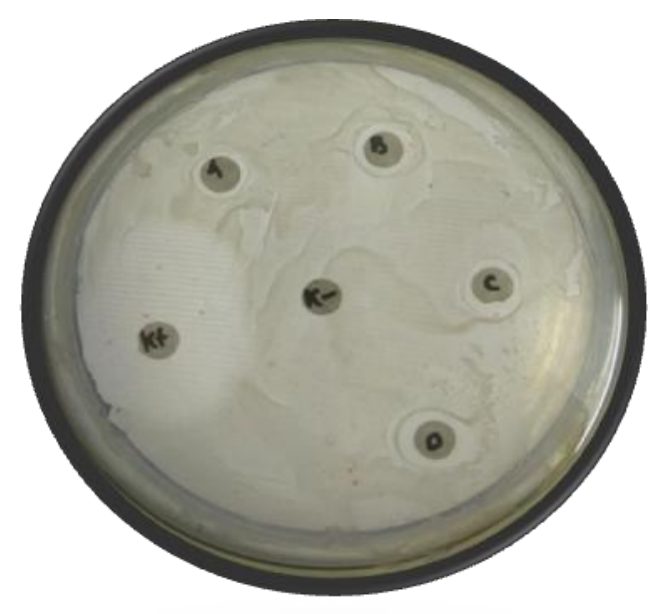

Gambar 1. Uji daya hambat ekstrak bawang hutan terhadap V. Harveyidengan perlakuan : A $(5 \mathrm{mg} / \mathrm{mL})$, B $(10 \mathrm{mg} / \mathrm{mL}), \mathrm{C}(20 \mathrm{mg} / \mathrm{mL}), \mathrm{D}(40 \mathrm{mg} / \mathrm{mL})$, $\mathrm{K}+$ (Kontrol positif dengan Chloramphenicol $30 \mathrm{mg} / \mathrm{mL}$ dan $5 \mathrm{mg} / \mathrm{mL}$ ), K- (kontrol negatif dengan akuades). 


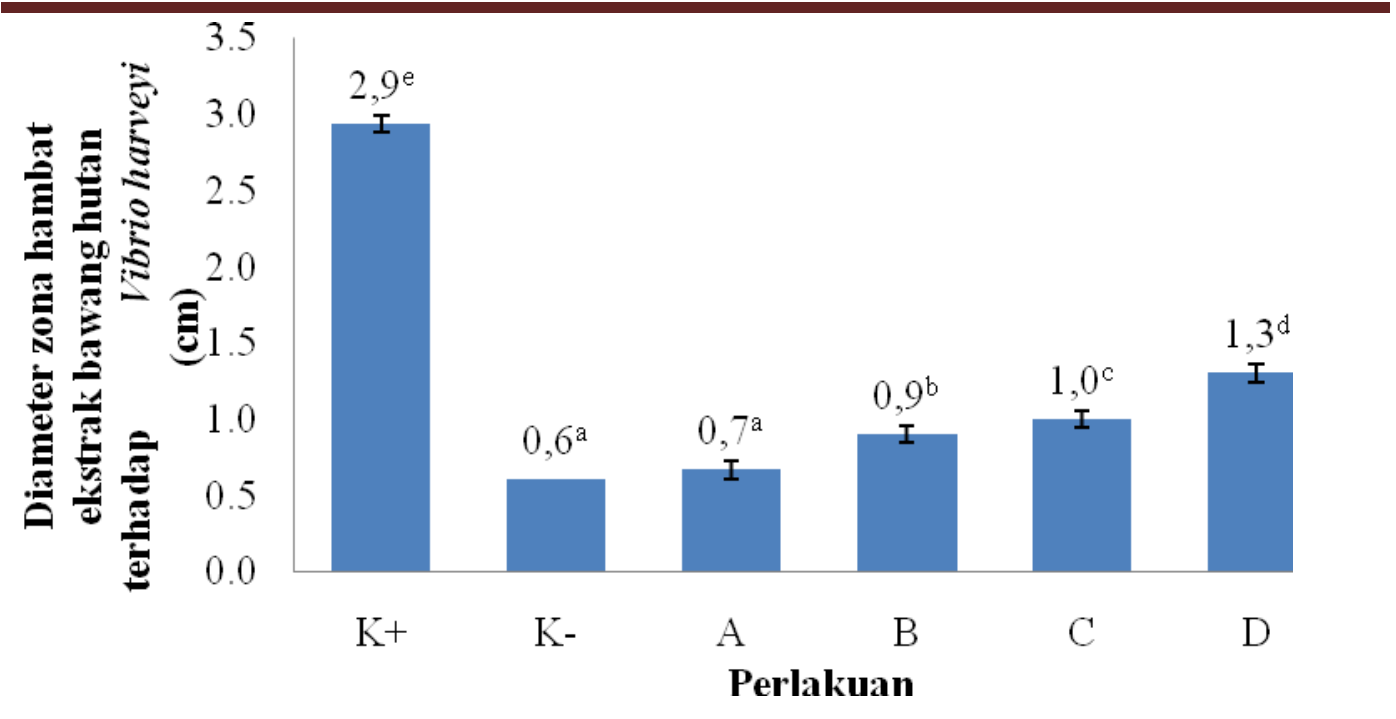

Gambar 8. Diameter zona hambat ekstrak bawang hutan terhadap $V$. harveyidengan perlakuan : A $(5 \mathrm{mg} / \mathrm{mL}), \mathrm{B}(10 \mathrm{mg} / \mathrm{mL}), \mathrm{C}(20$ $\mathrm{mg} / \mathrm{mL}), \mathrm{D}(40 \mathrm{mg} / \mathrm{mL}), \mathrm{K}+$ (Kontrol positif dengan menggunakan Chloramphenicol30 mg/mL), K- (kontrol negatif dengan akuades).

Ujidaya hambat ekstrak bawang hutan bertujuan untuk mengetahui dosis ekstrak bawang hutan yang dapat menghambat pertumbuhan bakteri $V$. harveyi. Pemberian ekstrak bawang hutan terlihat memiliki efek anti bakteri terhadap bakteri $V$. harveyi yang ditandai dengan terbentuknya zona bening. Zona hambat yang terbentuk berhubungan dengan senyawa - senyawa yang terkandung dalam ekstrak ekstrak bawang hutan yang dapat menghambat pertumbuhan bakteri. Menurut hasil penelitian Firdaus, (2014); Puspa dewi $d k k$., (2013), dari hasil uji fito kimia diketahui bahwa kandungan kimia dari ekstrak bawang hutan adalah alkaloid, flavonoid, saponin, tannin, glikosid, tripenoid, Diduga bahwa kandungan kimia dari ekstrak bawang hutan inilah yang dapat menghambat pertumbuhan bakteri. Senyawa - senyawa tersebut memiliki sifat anti bakteri dengan mekanisme yang berbeda - beda.

Menurut hasil penelitian dari Nuria $d k k$. (2009), flavonoid dapat membentuk senyawa kompleks dengan protein ekstra seluler dan terlarut sehingga mampu merusak membran sel bakteri yang diikuti dengan keluarnya senyawa intraseluler.

Senyawa terpenoid juga aktif melawan bakteri, tetapi mekanisme anti bacterial triterpenoid masih belum diketahui. Aktifitas anti bakteri dari senyawa terpenoid diduga melibatkan pemecahan membrane oleh komponen - komponen lipofilik (Bobbarala, 2012). Mekanisme kerja saponin sebagai anti bakteri yaitu menurunkan tegangan permukaan sehingga mengakibatkan naiknya permeabilitas atau kebocoran sel dan mengakibatkan senyawa intraseluler akan keluar (Nuriaet al. 2009). Zat yang dapat menghambat atau membunuh bakteri berupa garam garam logam, fenol atau senyawa lain yang sejenis, formaldehida, alcohol, yodium, kalor ataupersenyawaan, zat warna, detergen, sulfonamide, danantibiotik (Dwidjoseputro,1978). Saponin mempunyai kerja merusak membran plasma dari bakteri (Hopkins 1999). Menurut Robinson, 1995, mekanisme kerja saponin 
Jurnal Akuakultur Sungai dan Danau Vol. 4 No. 1 Tahun 2019 Hal. 15 - 20

sebagai anti bakteri adalah menurunkan tegangan permukaan sehingga mengakibatkan naiknya permiabilitas atau kebocoran sel dan mengakibatkan senyawa intraseluler akan keluar. Hasil penelitian Rosyidah et al. 2010. Menyatakan bahwa ekstrak saponin dari kulit batang tumbuhan kasturi (Mangiferacasturi) dapat menghambat pertumbuhan bakteri S. Aureus dan E. Coli.

Tanin memiliki aktivitas anti bakteri yang berhubungan dengan kemampuannya untuk menginaktifkan adhesion sel mikroba juga menginaktifkan enzim dan menggangu transpor protein pada lapisan dalam sel (Cowan 1999). Selanjutnya menurut Robinson, 1995, mekanisme kerja tannin sebagai anti bakteri adalah menghambat enzim reverse transcriptase dan DNA topoisomerase sehingga sel bakteri tidak dapat terbentuk. Hasil penelitian Safratilofa (2016), menyatakan bahwa ekstrak daun kayu manis mengandung golongan senyawa flavonoid, saponin dan tanin dapat menghambat pertumbuhan bakteri A.hydrophila.

Perbedaan konsentrasi ekstrak bawang hutan dalam menghambat pertumbuhan bakteri $A$. hydrophila dipengaruhi oleh beberapa hal diantaranya adalah konsentrasi ekstrak yang digunakan yang dapat mempengaruhi kemampuan dari bakteri dalam melakukan aktifitas melawan zat atau senyawa yang terkandung didalam ekstrak. Menurut Khunaifi (2010), salah satu faktor yang dapat mempengaruhi diameter zona hambat dan pola resistensi oleh bakteri adalah dengan cara menurunkan permiabel dinding sel bakteri sehingga antibakteri sulit masuk ke dalam sel, selain itu juga membentuk jalan pintas untuk menghindari tahap yang dihambat oleh antibakteri dan meningkatkan produk enzim yang dihambat oleh antibakteri.

\section{KESIMPULAN}

Ekstrak bawang hutan mampu menghambat pertumbuhan bakteri $V$. harveyi. Berdasarkan zona bening yang diperoleh pada uji daya hambat ekstrak bawang hutan bahwakonsentrasi terbesar yang mampu menghambat pertumbuhan bakteri $V$. Harveyi sebesar $1.3 \mathrm{~cm}$ pada konsentrasi $40 \mathrm{mg} / \mathrm{ml}$. Semakin tinggi konsentrasi daya hambat yang dihasilkan semakin besar.

\section{DAFTAR PUSTAKA}

Amanda FR. 2014. Efektivitas Ekstrak Bawang Dayak (Eleutherine palmifolia) dalam Menghambat Pertumbuhan Bakteri Escherichia coli. Skripsi. Program Studi Pendidikan Dokter, Fakultas Kedokteran dan Ilmu Kesehatan, Universitas Islam Negeri Syarif Hidayatullah. Jakarta.

Bobbarala, V. 2012. Antimicrobial Agents. Intech, Croatia.

CowanMM.1999. Plantproductsasantimicrobialagents.ClinicalMicrobiollogy Review.12: 564-582.

Firdaus, T. 2014. Efektivitas Ekstrak Bawang Dayak (Eleutherine palmifolia) dalam Menghambat Pertumbuhan Bakteri Staphylococcus aureus. Skripsi. Program Studi Pendidikan Dokter, Fakultas Kedokteran dan Ilmu Kesehatan, Universitas Islam Negeri Syarif Hidayatullah. Jakarta.

Hopkins WG. 1999. Introduction to Plant Physiology. Toronto: John Wiley and Sons, Inc. 
Jurnal Akuakultur Sungai dan Danau Vol. 4 No. 1 Tahun 2019 Hal. 15 - 20

Ifesan BOT, Hamstain C, Mahabusarakam W, Voravuthikunchhai. 2009. Inhibitory Effect of Eleutherine americana Merr. Extract on Staphylococcus aureus Isolated from Food. Journal of Food Science. 74(1):31-36.

Kamillah SN. 2014. Efektivitas Ekstrak Umbi Bawang Sabrang (Eleutherine palmifolia (L.) Merr.) terhadap Pertumbuhan Bakteri Streptococcus pyogenes. Skripsi. Program Studi Pendidikan Dokter, Fakultas Kedokteran dan Ilmu Kesehatan, Universitas Islam Negeri Syarif Hidayatullah. Jakarta.

Naafi'ah FA, 2014. Efektivitas Ekstrak Umbi Bawang Dayak (Eleutherine palmifolia (L.) Merr.) dalam Menghambat Pertumbuhan Bakteri Streptococcus pyogenes. Skripsi. Program Studi Pendidikan Dokter, Fakultas Kedokteran dan Ilmu Kesehatan, Universitas Islam Negeri Syarif Hidayatullah. Jakarta.

Nuria MC, Faizatun A, Sumantri. 2009. Uji Aktivitas Antibakteri Ekstrak Etanol Daun Jarak Pagar (Jatropha curcas L) terhadap Bakteri Staphylococcus aureus ATCC 25923, Escherichia coli ATCC 25922, dan Salmonella typhi ATCC 1408. Mediagro. 5(2):26-37.

Puspadewi R, Putranti A., Rizka M. 2013. Umbi Bawang Dayak (Eleutherine palmifolia (L.) Merr.) Sebagai Herbal Antimikroba Kulit. Kartika Jurnal Imiah Farmasi. 1(1):31-37.

RobinsonT. 1995. KandunganOrganikTumbuhanTinggi. Edisi ke-6.Terjemahan: K. Padmawinata. ITB-Press, Bandung.

Safratilofa. 2016. Uji Daya Hambat Ekstrak Daun Kayu Manis (Cinnamomum burmanni) Terhadap Bakteri Aeromonas hydrophila. Jurnal Ilmiah Universitas Batanghari Jambi. 16 : 98-103 